\title{
PSYCHE
}

Vol. 59

September, 1952

No. 3

\section{A NEW GENUS AND SPECIES OF SALDIDAE FROM SOUTH AMERICA (HEMIPTERA) ${ }^{1}$}

\section{By Carl J. Drake and Ludvik Hoberlandt Iowa State College, Ames}

Through the kindness of Dr. P. J. Darlington, Museum of Comparative Zoology (Harvard), the writers have been permitted to study some undetermined semiaquatic Hemiptera from widely separated areas of the world. The present paper contains the description of a new genus and new species of shore bug found on the beach of a small lake at an elevation of nearly 3,000 meters in the lofty Sierra Nevada de Santa Marta, Colombia, northern South America. The unit of measure is such that the formulas may be converted into millimeters by dividing by 80 . The authors are indebted to Mrs. R. E. Froeschner for the illustration of the type.

Oiosalda, n. gen.

Small, elongate-ovate, strongly convex above, remotely indistinctly pitted, black, shining. Head long, slender, almost porrect, slightly deflected, without distinct swellings or callosities, even in front. Eyes moderately large, distinctly excerted, moderately convergent anteriorly, deeply roundly notched within just a little back of the middle, the hind margins slightly removed from anterior margin of pronotum. Ocelli tiny, not placed on a raised area or tubercle, very widely separated, with the width of the space between them about three times the diameter of an ocellus, the space between an ocellus and an eye subequal to or feebly greater than the distance between the ocelli. Pronotum shallowly roundly emarginate behind, the collum not distinctly set-off, also no pronotal lobes;

1 Published with a grant from the Museum of Comparative Zoology at Harvard College. 
central part of pronotum strongly swollen and very wide, strongly and uniformly convex for its entire length, the swollen area extending laterally so as to leave no explanate margins, the lateral margins very narrow, carina-like, linear for its entire length. Scutellum slightly wider at base than median length. Hemelytra of brachypterous form strongly convex, decurved on the side so as to cover the sides of the abdomen, strongly coriaceous with areas and veins coalesced and obliterated; membrane entirely coriaceous with veins and cells indistinguishable, inseparable from the corium. Rostrum long, reaching between hind coxae. Legs moderately long, rather slender. Antennae rather long, quite slender; segment I moderately incrassate, stoutest; II longest, slender; III and IV slender, scarcely thicker than II. Macropterous form unknown.

Type of genus, Oiosalda caboti, n. sp.

Superficially, Oiosalda resembles the genus Lampracanthia Reuter, but it is easily differentiated by the very slender antennae, smaller and widely separated ocelli, and the indistinctly marked-off collum. In Lampracanthia, the antennae are strongly swollen, ocelli larger and approximate, humeral angles acutely produced, and the entire dorsal surface sparsely clothed with long erect hairs. The same characters as noted above also distinguish the new genus from Salda Fabricius.

Oiosalda caboti, n. sp.

Brachypterous form: Deep black, smooth, practically nude, very shining, the entire dorsal surface with only a few scattered, very short, inconspicuous, almost fleck-like pubescence of a golden color.

Size: Length, $3.00 \mathrm{~mm}$; width, $1.20 \mathrm{~mm}$.

Head: Width across eyes, $0.60 \mathrm{~mm}$.; median length, 1.20 $\mathrm{mm}$. Interocular space practically subequal to the width of an eye. Head black, feebly rugulose, without median longitudinal groove, without any callosities or strongly swollen areas, with two flavous spots on each side (one between an ocellus and an eye and other farther forward and just back

Explanation of Plate 9

Oiosalda caboti, new genus and species. 


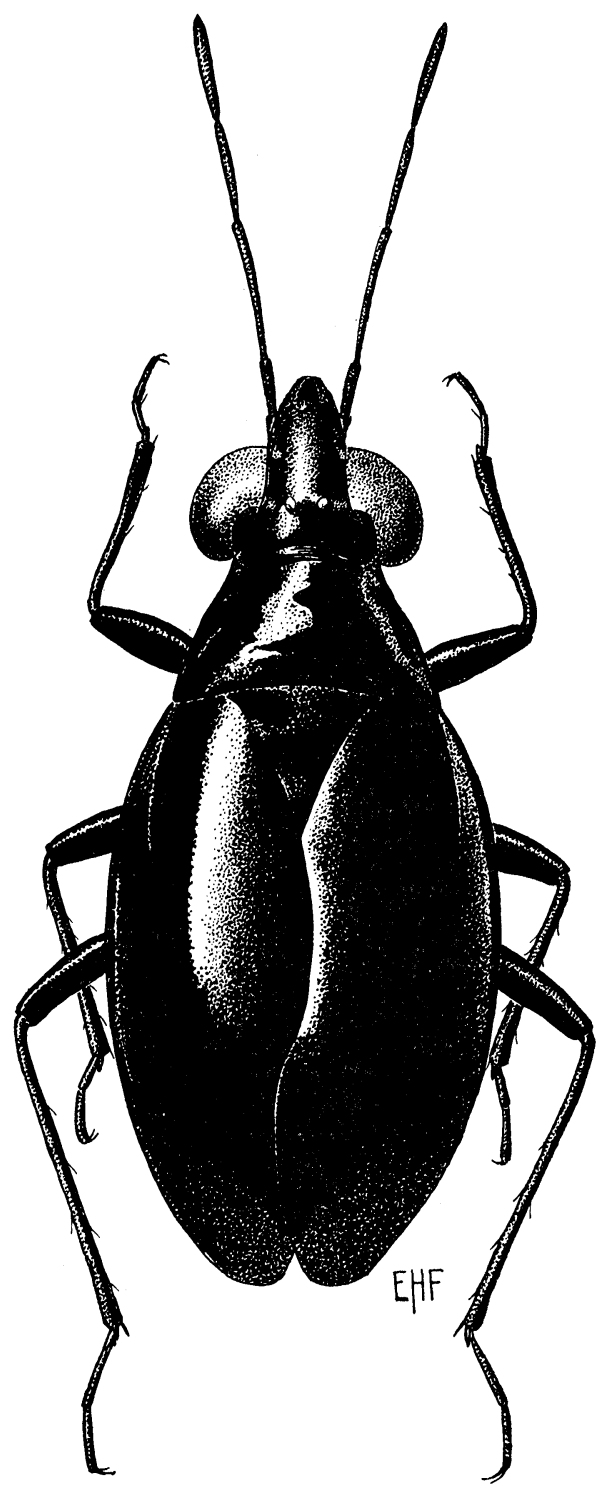

Drake and Hoberlandt - Otosalda caboti 
of front margin of eyes) ; clypeus rather narrow not quite twice as long as wide; labrum wide at base, roundly narrowed apically, shield-shaped, pointed at tip, almost twice as long as basal width, the base a little wider than apex of clypeus; apex of head, including labrum and corium, flavous. Rostrum rufo-fuscous, rather slender, extending between hind coxae. Head beneath black, clothed with short pale hairs. Antennae brownish fuscous, pubescent; formula-I, 20 ; II, 44-48; III, 30 ; IV, 35.

Pronotum: Pronotum almost twice as wide at base as median length $(80: 42)$, median length and width at anterior end nearly equal $(42: 45)$; humeral angles not produced or prominent; distinctly convex along its entire length, margins extremely narrow, carina-like, of uniform width from base to apex, very finely pitted. Scutellum almost flat, feebly transversely impressed at middle, a little wider at base than median length $(50: 40)$.

Hemelytra: Slightly wider at base than pronotum, decurved downwards on sides so as to envelope abdomen, indistinctly pitted, black, very shining, the outer margins narrowly turned outwards and there slightly embrowned; areas and veins all coalesced and not visible.

Legs: Moderately long, slender, brownish with femora mostly fuscous, sparsely clothed with short pale hairs; tibiae with usual dark brown spines. Acetabula, coxae and sternum black, the metasternum sometimes a little reddish. Abdomen beneath brown to black, clothed with short pale hairs. Male parameres not removed from type. Last venter of female whitish behind.

Type (male) and allotype (female), south side of the Sierra Nevada de Santa Marta, on shore of a small lake, 1941, Colombia, northern South America, collected by Dr. T. D. Cabot, in the Museum of Comparative Zoology (Harvard). Paratype, 1 male, in collection of C. J. Drake. Named in honor of the collector, Dr. Cabot.

This peculiar and striking little shore bug is so different from other species that it was necessary to erect a new genus for its reception; it is thus not readily confused with other described species. 

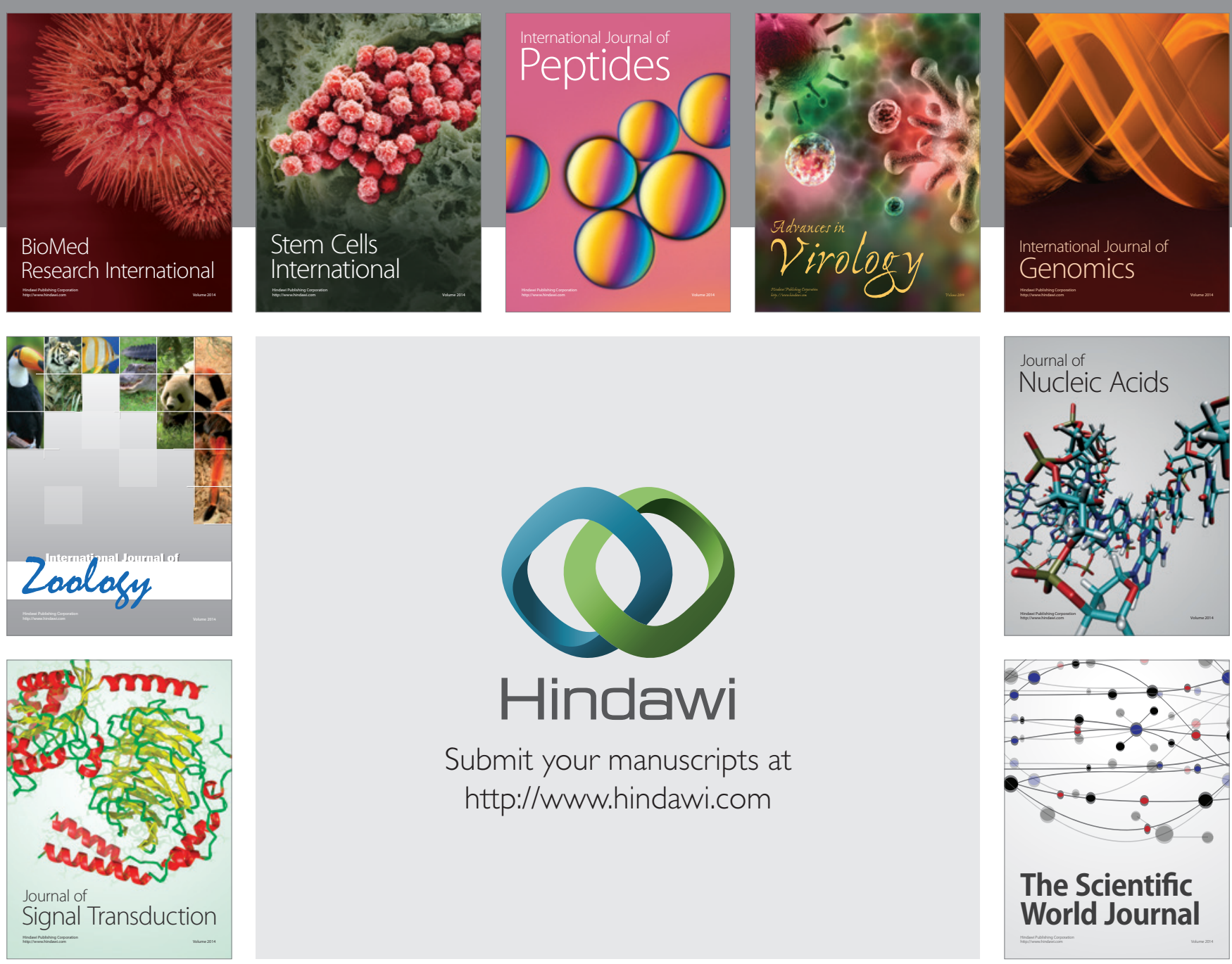

Submit your manuscripts at

http://www.hindawi.com
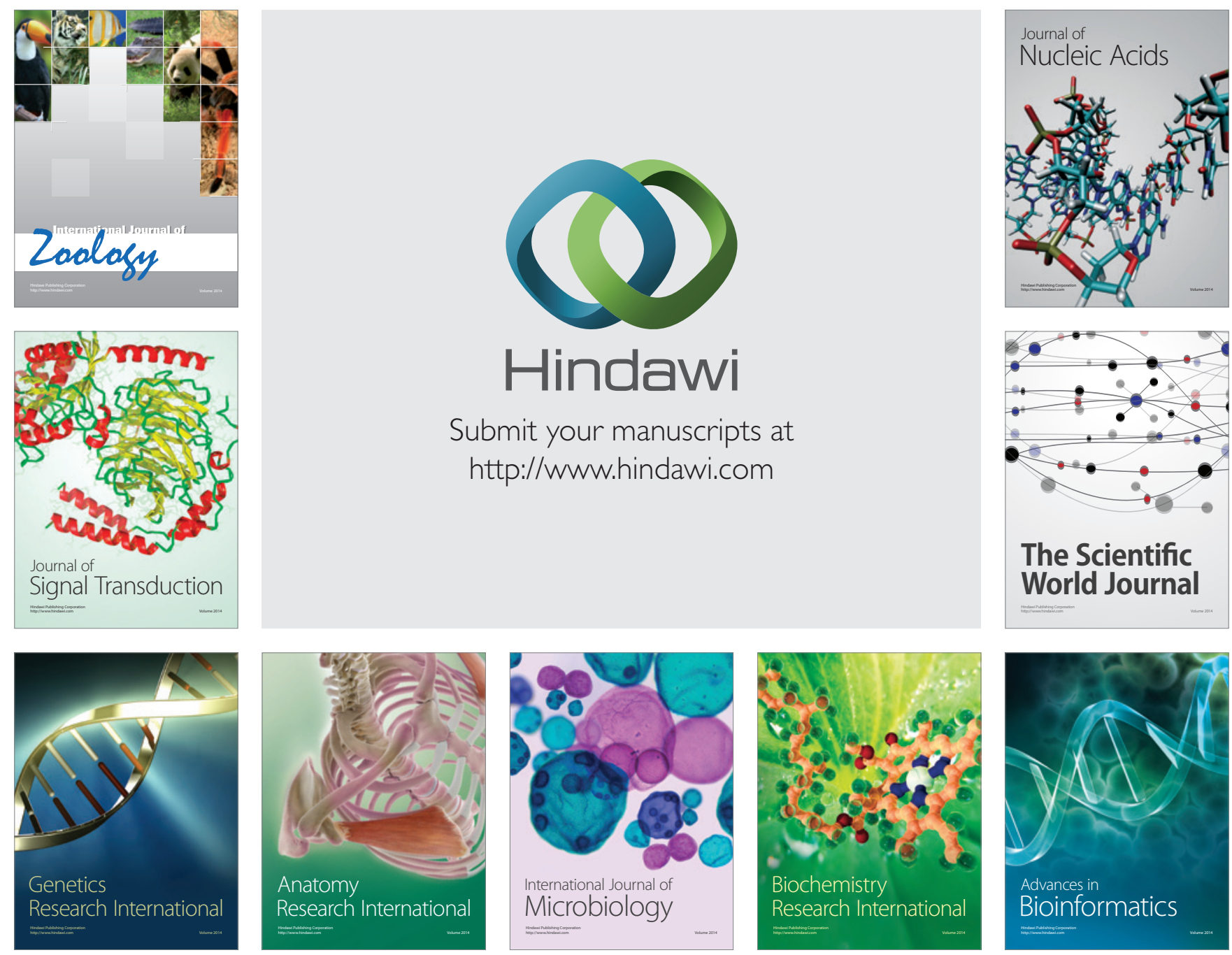

The Scientific World Journal
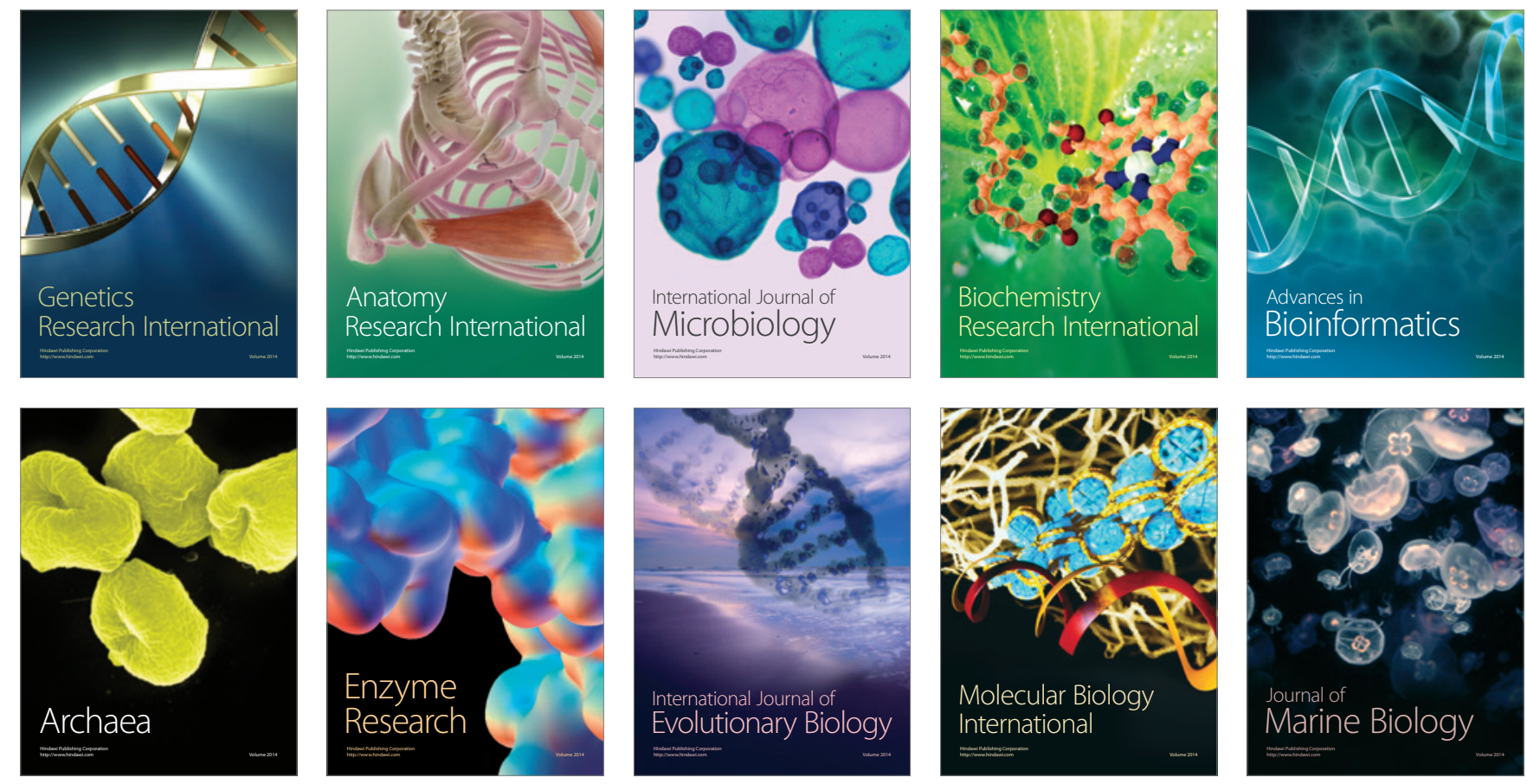